\title{
GJB2-RELATED NON-SYNDROMIC HEARING LOSS VARIANTS' SPECTRUM AND THEIR FREQUENCY IN TURKISH POPULATION
}

\author{
GJB2 ILIŞKILI NON-SENDROMIK IŞiTME KAYBI VARYANTLARININ SPEKTRUMU VE \\ TÜRK TOPLUMUNDAKI SIKLIKLARI
}

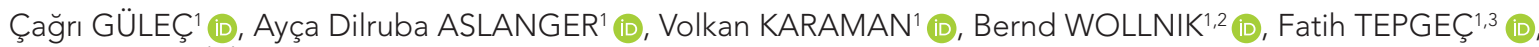 \\ Hülya KAYSERILi', (1D, Z. Oya UYGUNER ${ }^{1}$ (D)
}

\begin{abstract}
${ }^{1}$ Istanbul University, Istanbul Faculty of Medicine, Department of Medical Genetics, Istanbul, Turkey ${ }^{2}$ Institute of Human Genetics, University Medical Center Göttingen, Göttingen, Germany ${ }^{3}$ Altinbas University, Vocational School of Health Services, Department of Oral and Dental Health, Istanbul, Turkey ${ }^{4}$ Koç University School of Medicine (KUSOM), Department of Medical Genetics, Istanbul, Turkey
\end{abstract}

ORCID IDs of the authors: C..G. 0000-0002-1256-9574; A.D.A. 0000-0003-1770-1762; V.K. 0000-0001-8777-3548; B.V. 0000-0003-2589-0364; F.T. 0000-0001-8413-6949; H.K. 0000-0003-0376-499X; Z.O.U. 0000-0002-2035-4338

Cite this article as: Gulec C, Aslanger AD, Karaman V, Wollnik B, Tepgec F, Kayserili H, et al. GJB2-related non-syndromic Hearing loss variants' spectrum and their frequency in Turkish population. J Ist Faculty Med. Published online February 16, 2022. doi: 10.26650/IUITFD.1011501

\section{ABSTRACT}

Objective: Hearing loss $(\mathrm{HL})$ is one of the most prevalent chronic conditions in children and has consequences in speech, language, education, and social functioning which impede the quality of life. Due to the major involvement of the genetic factors in $\mathrm{HL}$, especially non-syndromic HL (NSHL), genetic diagnosis and genetic counseling have a major impact on early management of the affected individuals and their families. Herein, we report the GJB2 gene variants and their frequencies in NSHL cohort at a tertiary health center between 2002-2021 to contribute for the future genetic counseling of Turkish NSHL patients.

Materials and Methods: Two exons of the GJB2 gene were amplified in 402 NSHL patients by two separate PCR reactions and sequenced using the Sanger technique.

Results: We found 13 different GJB2 variants in 35\% (141/402) of the patients with NSHL. $53.9 \%$ were homozygous and $33.3 \%$ were compound heterozygous for the most common (59.21\%) variant, c. 35 delG. Approximately $13 \%$ of the patients were found to carry the variants in the heterozygous state. The most frequent GJB2 variant c.35delG was followed by c.71G>A (6.38\%), c. $-23+1 \mathrm{G}>\mathrm{A}(3.54 \%)$ and c.233delG (2.48\%). We found heterozygous p.Asp50Glu (c.150C>A) alteration in four of eight patients with keratitis, ichthyosis, deafness (KID) and palmoplantar keratoderma (PPK) syndrome.

Conclusion: Our results further emphasize the well-known prevalance of the GJB2 c.35delG alteration being the most pre-

\section{ÖZET}

Amaç: İşitme kaybı, çocukluk çağındaki en önemli kronik sağlık sorunlarından biridir ve yaşam kalitesini konuşma, eğitim ve sosyal ilişki sorunlarına yol açarak azaltır. Özellikle non-sendromik işitme kaybında genetik faktörlerin rolü etkilenmiş kişi ve ailelerinin genetik tanı ve genetik danışma aşamalarında doğru yönlendirilmesi açısından kilit bir rol oynar. Bu nedenle, non-sendromik işitme kaybı olan hasta ve ailelerinin önümüzdeki yıllarda genetik tanı ve danışmasına katkıda bulunmak amacıyla, bu çalışmada, 2002-2021 yılları arasında sinirsel tip işitme kaybı tanısı alan hastalardaki GJB2 gen varyantlarını ve sıklıklarını sunmaya çalıştık.

Gereç ve Yöntem: GJB2 geninin iki ekzonu, 402 hasta DNA'sında iki ayrı PCR ile çoğaltıldı ve Sanger yöntemi ile dizilendi.

Bulgular: Non-sendromik işitme kaybı olan olguların \%35'inde (141/402) GJB2 geninde 13 farklı değişim saptadık. Hastaların \%53,9'u en yaygın $(\% 59,21)$ varyant olan c.35delG değişimini homozigot taşırken, \%33,3'ü birleşik heterozigot olarak taşıyordu. Yaklaşı \%13'ünde ise değişim heterozigot olarak belirlendi. ÇaIışma grubumuzda en yaygın GJB2 varyantı olan c.35delG değişimini sırasıyla c.71G >A (\%6,38), c.-23+1G >A $(\% 3,54)$ ve c.233delG $(\% 2,48)$ değişimleri izlemiş̧ir. Keratit-ihtiyoz-sağırlık (KID) ve palmoplantar keratoderma (PPK) sendromu tanılı sekiz hastanın dördünde heterozigot p.Asp50Glu (c.150C >A) değişimi saptandı.

Sonuç: Sonuçlarımız, Türkiye'deki non-sendromik işitme kaybı hastalarındaki c.35delG varyantının uzun zamandır bilinen baskınlığını bir kez daha göstermektedir. Ayrıca, tek mutant alel

Corresponding author/iletişim kurulacak yazar: o.uyguner@istanbul.edu.tr

Submitted/Başvuru: 19.10.2021 • Revision Requested/Revizyon Talebi: 15.11.2021 •

Last Revision Received/Son Revizyon: 25.11.2021 • Accepted/Kabul: 13.01.2022 • Published Online/Online Yayın: 16.02 .2022 
dominant variant in the Turkish NSHL patients. The high rate of mono-allelic state could be considered as coincidental due to high allelic heterogeneity of NSHL, or possibly suggestive for digenic inheritance.

Keywords: Sensorineural hearing loss, GJB2 gene, c.35delG alteration, mutation frequency saptanan hastaların oranı, non-sendromik işitme kaybının alelik heterojenitesi nedeniyle rastlantısal olarak değerlendirilebileceği gibi, digenik kalıtımı da düşündürebilir.

Anahtar Kelimeler: Sinirsel tip işitme kaybı, GJB2 geni, c.35delG değişimi, mutasyon sıklığı

\section{INTRODUCTION}

Hearing loss (HL) is one of the important health problems with social and psychological outcomes. Though both environmental and genetic factors are involved in the etiology of $\mathrm{HL}$, hereditary factors are responsible for more than $70 \%$ of the cases. HL is classified as syndromic and non-syndromic, depending on the presence or the absence of accompanying findings, respectively. Non-syndromic $\mathrm{HL}$ (NSHL), which constitutes most of the cases (70-80\%), is further subdivided by mode of inheritance as autosomal recessive, autosomal dominant, $\mathrm{X}$-linked, and mitochondrial HL. Autosomal recessive NSHL (ARNSHL) constitutes $80 \%$ of NSHL (1). Bi-allelic variants in any one of the identified over 100 genes are known to cause ARNSHL. This considerable number of genes responsible for hearing loss shows the hearing mechanism's complex structure which involves channel proteins, integral membrane protein, adhesion molecules, enzymes and extracellular matrix components (2). However, the most frequent mutations causative for ARNSHL are found in the GJB2 gene.

The GJB2 (CX26, GenBank M86849, OMIM: *121011) gene encodes connexin protein providing a chemical connection of the cell with neighboring cells or extracellular space. The main task of GJB2 in the hearing system is to modulate the potassium ion recycling which is required for the action potentials of hair cells in the organ of Corti (3-6). Generally, loss-of-function mutations of the GJB2 gene cause autosomal recessive non-syndromic hearing loss (ARNSHL). In contrast, gain-of-function mutations of the GJB2 gene are responsible for the autosomal dominant keratitis, ichthyosis, deafness (KID) or palmoplantar keratoderma (PPK) syndrome, characterized by extensive hyperkeratotic lesions in the skin, keratitis leading to a loss of visual acuity and profound progressive deafness (7).

Diversity in the clinical manifestations of GJB2 variants can mainly explain the genotype-phenotype correlation. The nonsense mutations causing early truncation and missense mutations preventing the formation of gap junctions may be responsible for profound hearing loss. Some other particular alterations do not impair the formation of functional gap junctions but reduce conductance levels and alter gating properties, causing mild or moderate hearing loss (8-10). On the other hand, GJB2 mutations like p.Asp50Glu (c.150C>A), p.Gly12Arg (c.34G >C),
p.Ala40Val (c.119C>T), and p.Gly45Glu (c.134G >A) which are associated with KID/PPK do not seem to impair the gap junction formation, but they mildly affect gap junction channel properties $(11,12)$.

ARNSHL's prevalence depends on the frequency of carriers in the population. Knowing the frequency and types of mutation in a population allows early therapeutic intervention. As a result of recent developments in genetic technology, the diagnostic approach to patients with hearing loss now includes Whole Exome Sequencing (WES) after scanning of the GJB2 gene. Thus, for the appropriate implementation of the GJB2 gene scanning in a population, the variant frequency data may need to be updated. In this regard, we aimed to investigate the frequency and spectrum of GJB2 gene variants in our NSHL patients diagnosed with GJB2-related disease (ARNSHL).

\section{MATERIALS AND METHODS}

The bilateral hearing-loss patients with clinical findings that suggest a possible traumatic or infectious causative, and unilateral hearing-loss patients were excluded from the study. The patients with a syndromic form of hearing loss, except for those with KID or PPK, were also excluded.

Peripheral blood samples of $2 \mathrm{ml}$ were collected upon approval of the patients and families for genetic testing. DNA isolations were performed by using commercial kits according to the instructions (Mammalian Blood and Cells and Tissue DNA Isolation Kit, Roche). Two exons of the GJB2 gene were amplified by three separate PCR reactions using specific primers (Table 1). To perform an efficient sequencing, the second exon of the GJB2 gene, which has a relatively large size (681 bp), was amplified and sequenced with two separate PCRs. All PCR reactions were carried out with $2.5 \mathrm{mM} \mathrm{MgCl} 2,0.2 \mu \mathrm{M}$ of each primers, $0.2 \mu \mathrm{M}$ of each dNTP, $1 \mathrm{U}$ Taq DNA polymerase (Thermo Fisher Scientific) and 100 ng genomic DNA. Purification of the PCR products was performed with Exonuclease and Alkaline Phosphatase enzymes (Thermo Fisher Scientific). Sanger sequencing reactions were carried out with an automated sequencer (ABI 3500). An analysis of sequencing data was performed with the SeqScape software (SeqScape v3.0) using the GJB2 reference requence (NM_004004.6) fetched from the USCS Genome Browser (https://genome-euro.ucsc.edu/). The study was approved by the Ethics Committee of Istanbul University, Istanbul Faculty of Medicine (Date: 22.01.2021, No: 108). 
Table 1: Primers used to amplify non-coding and coding two exons of GJB2 gene

\begin{tabular}{|c|c|c|c|c|c|}
\hline Primer & Exon & Sequence & $\begin{array}{l}\text { Lenghth } \\
\text { (bp) }\end{array}$ & $\operatorname{Tm}\left({ }^{\circ} \mathrm{C}\right)$ & $\begin{array}{l}\text { Expected PCR } \\
\text { product size (bp) }\end{array}$ \\
\hline GJB2_F1 & \multirow{2}{*}{1} & 5'-GTGCGGTTAAAAGGCGCCA-3' & 19 & 66.4 & \multirow{2}{*}{265} \\
\hline GJB2_R1 & & 5'-GGCAACCGCTCTGGGTCT-3' & 18 & 63.8 & \\
\hline GJB2_F2-I & \multirow{2}{*}{2} & 5'-CTCCCTGTTCTGTCCTAGCT-3' & 20 & 56.2 & \multirow{2}{*}{840} \\
\hline GJB2_R2_I & & 5'-GACTGAGCCTTGACAGCTGA-3' & 20 & 59.3 & \\
\hline GJB2_F2-II & \multirow{2}{*}{2} & 5'-CTCCCTGTTCTGTCCTAGCT-3' & 20 & 56.2 & \multirow{2}{*}{804} \\
\hline GJB2_R2-II & & 5'-СССТCTCATGCTGTCTATTTC-3' & 21 & 56.5 & \\
\hline
\end{tabular}

bp: Base pair, Tm: Melting temparature

\section{RESULTS}

Among 402 families with at least one member clinically diagnosed with ARNSHL based on pedigree, 35\% $(141 / 402)$ were found to carry the pathogenic variant in the GJB2 gene. Of these, $53.9 \%$ were homozygous, and $33.3 \%$ were compound heterozygous for the identified variants. Approximately $13 \%$ of the patients were found to carry a single (mono-allelic) GJB2 variant (Table 2).

We identified 13 different GJB2 gene variants in our cohort (Table 2). The GJB2 gene variants most frequently observed were c.35delG (59.2\%), c.71G $>$ A (6.38\%), c.$23+1 \mathrm{G}>\mathrm{A}(3.54 \%)$, c.233delC (2.48\%) and c.358_360delGAG (1.77\%). Five variants (c.35delG, c.71G >A, c.23+1G >A, c.358_360delGAG and c.233delC) were found in the homozygous state, seven were found to be compound heterozygotes, c.35delG being the most frequent one. One patient was found to be compound heterozygous, involving different alleles other than c.35delG. Eighteen (12.7\%) of the patients were found to carry a single GJB2 variant, most frequently (55\%) being c.35delG.

Allele (Figure 1) and genotype frequencies (Table 3) consistently showed that c.35delG variant predominates the cohort either in homozygous or in compound heterozygous state. The c.71G >A variant was the second most frequent one.

In eight patients clinically diagnosed with KID syndrome four were found to carry c.150C>A (p. Asp50Glu).

Table 2: Patient allele counts of GJB2 variants revealed in the NSHL cohort

\begin{tabular}{|c|c|c|c|c|c|c|}
\hline \multirow[b]{2}{*}{ Mutation } & \multicolumn{3}{|c|}{ Patient counts } & \multirow[b]{2}{*}{$\begin{array}{l}\text { Allele } \\
\text { count }\end{array}$} & \multirow{2}{*}{$\begin{array}{c}\text { Allele } \\
\text { frequency }\end{array}$} & \multirow[b]{2}{*}{ Reference } \\
\hline & Homozygous & $\begin{array}{c}\text { Compound } \\
\text { heterozygous }\end{array}$ & Mono-allelic & & & \\
\hline c.35delG (p.G12Vfs*2) & 67 & 23 & 10 & 167 & 76.82 & 13 \\
\hline c.71G >A (p.W24*) & 3 & 12 & 0 & 18 & 8.19 & 14 \\
\hline c. $-23+1 \mathrm{G}>\mathrm{A}$ & 2 & 3 & 3 & 10 & 4.56 & 15 \\
\hline c.233delC (p.L79Cfs*3) & 2 & 3 & 0 & 7 & 3.18 & 16 \\
\hline c.358_360delGAG (p.E120del) & 2 & 0 & 1 & 5 & 2.73 & 17 \\
\hline c.167delT (p.L56Rfs*26) & 0 & 2 & 0 & 2 & 0.91 & 18 \\
\hline c.269T>C (p.L90P) & 0 & 1 & 1 & 2 & 0.91 & 13 \\
\hline c.327_328delGG (p.E110Dfs*4) & 0 & 1 & 0 & 1 & 0.45 & 19 \\
\hline c.439G > T (p.E147*) & 0 & 1 & 0 & 1 & 0.45 & 20 \\
\hline c.94C>T (p.R32C) & 0 & 1 & 0 & 1 & 0.45 & 21 \\
\hline c.487A>G (p.M163V) & 0 & 0 & 1 & 1 & 0.45 & 22 \\
\hline c.551G > C (p.R184P) & 0 & 0 & 1 & 1 & 0.45 & 18 \\
\hline c.239A> G (p.Q80R) & 0 & 0 & 1 & 1 & 0.45 & 33 \\
\hline Total & $76(53.91 \%)$ & $50(33.33 \%)$ & $18(12.76 \%)$ & 220 & & \\
\hline
\end{tabular}




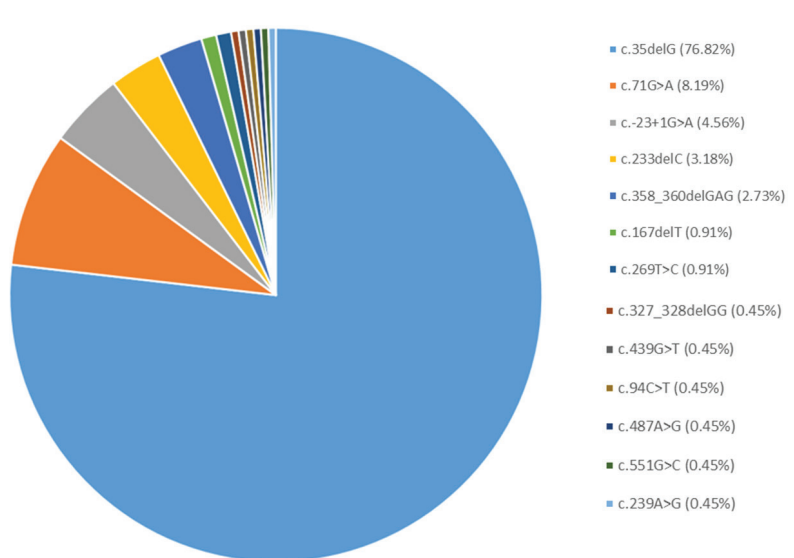

Figure 1: Allele frequency of GJB2 variants identified in the cohort. neighboring countries. The most frequent variant was c.35delG, which was identified in more than half of our patients. This mutation is the most common pathogenic variant found among Caucasians, Mediterraneans, and different European populations (12, 23-27). Though c. 35 delG was reported as the most frequent alteration by different studies in various countries, its frequency was not the same among populations. The variable frequency of c.35delG among different populations can be explained by the founder effect. Many studies suggest that the c.35delG allele originated from South Europe, Italy (28). Interestingly, the frequency of this variant displays a geographic gradient as observed by its frequency decrease from Southern to Northern Europe and from Western to Eastern Asia (29). This geographic gradient can be

Table 3: Patients with different GJB2 allele genotypes in the cohort

\begin{tabular}{|c|c|c|}
\hline Genotype (HGVS*) & Zygosity & Patient Count (\%) \\
\hline c.[35delG];[35delG] & Homozygous & $67(56.78)$ \\
\hline c. [35delG];[71G>A] & Compound Heterozygous & $12(10.17)$ \\
\hline c. [35delG];[35=] & Heterozygous & $10(8.47)$ \\
\hline c.[35delG];[233delC] & Compound Heterozygous & $3(2.54)$ \\
\hline c. $[71 \mathrm{G}>\mathrm{A}] ;[71 \mathrm{G}>\mathrm{A}]$ & Homozygous & $3(2.54)$ \\
\hline c. [35delG];[-23+1G>A] & Compound Heterozygous & $3(2.54)$ \\
\hline c. $[-23+1 \mathrm{G}>\mathrm{A}] ;[-23=]$ & Heterozygous & $3(2.54)$ \\
\hline c.[358_360delGAG];[358_360delGAG] & Homozygous & $2(1.69)$ \\
\hline c.[35delG];[167delT] & Compound Heterozygous & $2(1.69)$ \\
\hline c.[233delC];[233delC] & Homozygous & $2(1.69)$ \\
\hline c. $[-23+1 G>A] ;[-23+1 G>A]$ & Homozygous & $2(1.69)$ \\
\hline c.[358_360delGAG];[358_360=] & Heterozygous & $1(0.85)$ \\
\hline c.[35delG];[327_328delGG] & Compound Heterozygous & $1(0.85)$ \\
\hline c.[35delG];[439G>T] & Compound Heterozygous & $1(0.85)$ \\
\hline c.[35delG];[94C>T] & Compound Heterozygous & $1(0.85)$ \\
\hline c.[269T>C];[358_360 delGAG] & Compound Heterozygous & $1(0.85)$ \\
\hline c. $[269 T>C] ;[269=]$ & Heterozygous & $1(0.85)$ \\
\hline c. $[487 A>G] ;[487=]$ & Heterozygous & $1(0.85)$ \\
\hline c. $[551 \mathrm{G}>\mathrm{C}] ;[551=]$ & Heterozygous & $1(0.85)$ \\
\hline c. [239A>G];[239=] & Heterozygous & $1(0.85)$ \\
\hline
\end{tabular}

*: Human Genome Variation Society (http://varnomen.hgvs.org/recommendations/DNA/)

\section{DISCUSSION}

Here we report, the variant spectrum and frequency of the GJB2 gene in NSHL patients with GJB2-related entities (ARNSHL or KID/PPK). Our results were consistent with the previous studies conducted in Turkey or in observed even in some individual countries. In Iran, for instance, the frequency of the c.35delG is highest in the North-West and lowest in the South-East populations, consistent with the findings of neighboring countries like Turkey and Pakistan (30). A similar frequency range for 
c.35delG variant has been observed in different cities of Turkey ranging from 5\% to 53\% (31).

$\mathrm{HL}$ is a health problem, although being nonlethal it poses life quality issues. Though the recent developments in $\mathrm{HL}$ treatment partly begin to overcome these limitations, the psychological outcomes of the disease can not be ignored. The current solutions to this problem include early diagnosis, management, follow-up, educational and social support for the families, genetic counseling, and possible cochlear implantation. Due to the high rate of heredity in $\mathrm{HL}$, genetic counseling has a major impact on new cases before genetic testing. On the other hand, the high ratio of autosomal recessive inheritance calls attention to consanguineous marriages. Many studies suggest that the variability in the frequency of some GJB2 variants in different populations resulted from the founder effect for the frequent variants and consanguineous marriages for the rare variants $(15,29,31)$. Within our cohort, five alterations in a homozygous state were consistent with their high frequency of consanguineous marriages in the population from Turkey. As a result of high allele frequency, c.35delG was found in $87 \%$ and $46 \%$ of the patients at homozygous and compound heterozygous state, respectively. These ratios may clinically have importance because c.35delG mutation has been shown to have significantly severe hearing impairment in homozygous patients, compared with 35delG/non-35delG compound heterozygotes (8). Interestingly, one of our patients who was in a compound heterozygous state had two different mutations (c.[269T>C;358_360delGAG]) other than the most frequent one (c.35delG). Taken together with the high ratio of compound heterozygosity, this finding suggests that ARNSHL is a health problem not restricted to consanguineous marriages.

Some GJB2 mutations reported previously from Turkey were not found in our patient cohort (32). These variants include c.360_362delGAT (p.delE120), c.310_323del14, c.299_300delAT, c.517C $>T$ (p.P173S) and c.238C $>A$ (p.Q80K). This discrepancy supports the idea that the GJB2 variant spectrum and frequencies vary by geographic origins and the size of the cohorts. Even in the same cohort, the spectrum of variants can fluctuate by the method used and by the size of the cohort. For instance, compared to our previous report, we observed in this present study an additional ten rare variants and one frequent variant (c.-23+1G>A) in the GJB2 gene due to the inclusion of the non-coding exon of GJB2 and the analysis of a higher number of patients (33).

The finding that $12.7 \%$ of our patients had a single mutant allele of the GJB2 gene suggests some possibilities, like the presence of a second mutation that might be located in a non-coding or regulatory regions of the GJB2 gene. Another possibility is that the bi-allelic mu- tations responsible for the disease might be located in a different gene other than the GJB2. In the latter case, the mutation we found in the GJB2 gene might be just a coincidental variant carried by the patient. However, digenic inheritance involving the GJB2 gene should also be considered to explain mono-allelic GJB2 gene variants in the patients. Digenic inheritance in ARNSHL was reported by previous studies $(34,35)$. Mono-allelic variant carriers of the GJB2 gene were shown to cause ARNSHL with the presence of other mono-allelic variants in another gene like GJB6, GJB3, MITF, TMPRSS3, GJB4, GJA1, and GJC3 (36-40). However, there are conflicting data regarding TMPRSS3/GJB2 digenic inheritance (41). Despite all the supporting publications, the molecular mechanism underlying the digenic ARNSHL remains to be elucidated. Considering all these data, we can at least say that, to elucidate the molecular etiology of ARNSHL in the patients with mono-allelic GJB2 mutation, digenic inheritance should be kept in mind. For such patients, exome sequencing is presently recommended for genetic diagnosis. However, to confirm the digenic inheritance, a segregation analysis of the candidate variants in the patient's family is also needed. Besides, digenic inheritance carries a possibility of a lead to an incorrect exclusion of the variant in segregation analysis.

In addition to the patients with ARNSHL, we analyzed the GJB2 gene in the patients with KID/PPK syndrome. Of eight patients clinically diagnosed with KID/PPK, four were found to carry p.D50N (c.150C >A) variant in heterozygous state. Though this study covered only the GJB2 gene, variants in other connexin genes like GJB6 (CX30), GJB4 (CX30.3), GJB3 (CX31), and GJA1 (CX43) that are expressed in epidermis and appendages, are known to cause skin disorders (42). However, only GJB6 variants are known to cause KID/PPK or an overlapping Clouston syndrome (43). Like GJB2, GJB6 also has allelic heterogeneity, and pathogenic GJB6 variants can cause autosomal recessive and dominant deafness or type 2 ectodermal dysplasia 2 (Clouston type). Therefore, sequencing of the GJB6 gene should be included in the diagnostic algorithm of the HL patients with skin lesions.

The GJB2 gene has two exons, and most pathogenic GJB2 variants, including c.35delG, are located in the second exon of the gene. Therefore, sequencing of this exon is expected to detect most of the causative variants. Consistent with previous studies, sequencing of the second exon was sufficient for the diagnosis of most patients. However, our patients' third most frequent mutation (c. $-23+1 \mathrm{G}>\mathrm{A}$ ) is located in the splicing site of the non-coding first exon. Sequencing of this non-coding exon is also required to increase the diagnostic yield of the patients with ARNSHL. 
In summary, sequencing only the coding exons of the GJB2 gene would lead to molecular diagnosis in approximately $33 \%$ of the patients. Further, including the non-coding exon would yield an additional $2 \%$ diagnostic rate. To identify pathogenic variants in the remaining $65 \%$ of the cases, it seems necessary to implement NGS techniques, due to the possible digenic inheritance and multigenic etiology of NSHL. Increasing the availability and decreasing the cost of the NGS have made it the most favorable technique for the diagnosis of genetic diseases in the past years. Depending on the GJB2 mutation spectrum and frequency in a population, NGS seems to be a recommendable method after excluding the most frequent mutations by Sanger sequencing. It should be noted that the NGS technique may reveal some coincidental variants that could be confusing for the clinician.

The efficiency of NGS in the diagnosis of $\mathrm{HL}$ depends both on the cohort and the covered genes. Depending on the patient selection criteria (like ethnicity, with or without positive family history), a positive diagnostic rate was reported to range from 10 to $83 \%$ (44). Similarly, in a large multiethnic cohort including 1119 unrelated patients who were tested with NGS gene panel (targeted genomic enrichment and massively parallel sequencing), it was shown that screening of 89 genes increased the diagnostic rate by $2 \%$ compared to the screening of 66 genes. This difference was stated to account for $4 \%$ of all positive diagnoses (45). Considering the remarkable contribution rate (18\%) of gross copy number changes in hearing loss, we can deduce that the MLPA technique may also need to be implemented for the diagnostic algorithm of NSHL (35).

In conclusion, our update on NSHL cohort for GJB2-related entities has supported the previous knowledge about the most frequent GJB2 pathogenic variants and revealed the possibility of compound heterozygosity of the rare variants and potential digenic inheritance.

Informed Consent: Written consent was obtained from the participants.

Ethics Committee Approval: This study was approved by the Ethics Committee of Istanbul University, Istanbul Faculty of Medicine (Date: 22.01.2021, No: 108).

Peer Review: Externally peer-reviewed.

Author Contributions: Conception/Design of Study- Z.O.U., B.W.; Data Acquisition- H.K., A.D.A.; Data Analysis/Interpretation- Z.O.U., V.K., F.T., Ç.G.; Drafting Manuscript- Ç.G., Z.O.U.; Critical Revision of Manuscript- Z.O.U., H.K., Ç.G.; Approval and Accountability- Z.O.U., H.K., B.W., Ç.G., A.D.A., V.K., F.T.

Conflict of Interest: Authors declared no conflict of interest
Financial Disclosure: Authors declared no financial support.

Acknowledgement: We especially thank to Psychologist Melike Ulubil for her support in the ascertainment of the families and for meticulously drawn pedigrees. We remember the esteemed Nermin Baserer, Professor of the Ear, Nose and Throat Department of Istanbul Faculty of Medicine, with appreciation, and respect for her valuable support on the genetics of hearing loss. We always remember Abdullah Üzümcü, PhD with love, respect, and vivid memories.

\section{REFERENCES}

1. Kelsell DP, Dunlop J, Stevens HP, Lench NJ, Liang JN, Parry $\mathrm{G}$, et al. Connexin 26 mutations in hereditary non-syndromic sensorineural deafness. Nature 1997;387(6628):80-3. [CrossRef]

2. Tekin M, Arnos KS, Pandya A. Advances in hereditary deafness. Lancet 200;358(9287):1082-90. [CrossRef]

3. Lautermann J, ten Cate WJ, Altenhoff P, Grümmer R, Traub $\mathrm{O}$, Frank $\mathrm{H}$, et al. Expression of the gap-junction connexins 26 and 30 in the rat cochlea. Cell Tissue Res 1998;294(3):41520. [CrossRef]

4. Forge A, Becker D, Casalotti S, Edwards J, Marziano N, Nevill G. Gap junctions in the inner ear: comparison of distribution patterns in different vertebrates and assessement of connexin composition in mammals. J Comp Neurol 2003;8;467(2):207-31. [CrossRef]

5. Zhao HB, Yu N. Distinct and gradient distributions of connexin26 and connexin30 in the cochlear sensory epithelium of guinea pigs. J Comp Neurol 2006;20;499(3):506-18. [CrossRef]

6. Majumder P, Crispino G, Rodriguez L, Ciubotaru CD, Anselmi F, Piazza V, et al. ATP-mediated cell-cell signaling in the organ of Corti: the role of connexin channels. Purinergic Signal 2010;6(2):167-87. [CrossRef]

7. Caceres-Rios H, Tamayo-Sanchez L, Duran-Mckinster C, de la Luz Orozco M, Ruiz-Maldonado R. Keratitis, ichthyosis, and deafness (KID syndrome): review of the literature and proposal of a new terminology. Pediatr Dermatol 1996;13(2):105-13. [CrossRef]

8. Cryns K, Orzan E, Murgia A, Huygen PL, Moreno F, del Castillo I, et al. A genotype-phenotype correlation for GJB2 (connexin 26) deafness. J Med Genet 2004;41(3):147-54 [CrossRef]

9. Meşe G, Londin E, Mui R, Brink PR, White TW. Altered gating properties of functional Cx26 mutants associated with recessive non-syndromic hearing loss. Hum Genet 2004;115(3):191-9. [CrossRef]

10. Beltramello M, Piazza V, Bukauskas FF, Pozzan T, Mammano F. Impaired permeability to $\operatorname{Ins}(1,4,5) \mathrm{P} 3$ in a mutant connexin underlies recessive hereditary deafness. Nat Cell Biol 2005;7(1):63-9. [CrossRef]

11. Lee JR, Derosa AM, White TW. Connexin mutations causing skin disease and deafness increase hemichannel activity and cell death when expressed in Xenopus oocytes. J Invest Dermatol 2009;129(4):870-8. [CrossRef]

12. Gasparini P, Rabionet R, Barbujani G, Melçhionda S, Petersen M, Brøndum-Nielsen K, et al. High carrier frequency of the 35delG deafness mutation in European populations. Genetic Analysis Consortium of GJB2 35delG Eur J Hum Genet 2000;8(1):19-23. [CrossRef] 
13. Safka Brozkova D, Uhrova Meszarosova A, Lassuthova P, Varga L, Staněk D, Borecká S, et al. The Cause of Hereditary Hearing Loss in GJB2 Heterozygotes-A Comprehensive Study of the GJB2/DFNB1 Region. Genes (Basel) 2021;1;12(5):684. [CrossRef]

14. Hegde S, Hegde R, Kulkarni SS, Das KK, Gai PB, Bulgouda R. Molecular alteration in the Gap Junction Beta 2 (GJB2) gene associated with non-syndromic sensorineural hearing impairment. Intractable Rare Dis Res 2021;10(1):31-6. [CrossRef]

15. Mani RS, Ganapathy A, Jalvi R, Srikumari Srisailapathy CR, Malhotra V, Chadha $S$, et al. Functional consequences of novel connexin 26 mutations associated with hereditary hearing loss. Eur J Hum Genet 2009;17(4):502-9. [CrossRef]

16. Wu CC, Tsai $C H$, Hung CC, Lin $Y H$, Lin $Y H$, Huang $F L$, et al. Newborn genetic screening for hearing impairment: a population-based longitudinal study. Genet Med 2017; 19(1):6-12. [CrossRef]

17. Morgan A, Lenarduzzi S, Spedicati B, Cattaruzzi E, Murru FM, Pelliccione G, et al. Lights and Shadows in the Genetics of Syndromic and Non-Syndromic Hearing Loss in the Italian Population. Genes (Basel) 2020;22;11(11):1237. [CrossRef]

18. Pandya A, O'Brien A, Kovasala M, Bademci G, Tekin M, Arnos KS. Analyses of del(GJB6-D13S1830) and del(GJB6-D13S1834) deletions in a large cohort with hearing loss: Caveats to interpretation of molecular test results in multiplex families. Mol Genet Genomic Med 2020;8(4):e1171. [CrossRef]

19. Bazazzadegan N, Nikzat N, Fattahi Z, Nishimura C, Meyer $N$, Sahraian S, et al. The spectrum of GJB2 mutations in the Iranian population with non-syndromic hearing loss--a twelve year study. Int J Pediatr Otorhinolaryngol 2012;76(8):1164-74. [CrossRef]

20. Gardner P, Oitmaa E, Messner A, Hoefsloot L, Metspalu A, Schrijver I. Simultaneous multigene mutation detection in patients with sensorineural hearing loss through a novel diagnostic microarray: a new approach for newborn screening follow-up. Pediatrics 2006;118(3):985-94. [CrossRef]

21. Prasad S, Cucci RA, Green GE, Smith RJ. Genetic testing for hereditary hearing loss: connexin 26 (GJB2) allele variants and two novel deafness-causing mutations (R32C and 645-648delTAGA). Hum Mutat 2000;16(6):502-8. [CrossRef]

22. Buonfiglio $P$, Bruque $C D$, Luce $L$, Giliberto $F$, Lotersztein $V$, Menazzi S, et al. GJB2 and GJB6 Genetic Variant Curation in an Argentinean Non-Syndromic Hearing-Impaired Cohort. Genes (Basel) 2020;11(10):1233. [CrossRef]

23. Riahi Z, Zainine R, Mellouli $Y$, Hannachi R, Bouyacoub $Y$, Laroussi $N$, et al. Compound heterozygosity for dominant and recessive GJB2 mutations in a Tunisian family and association with successful cochlear implant outcome. Int J Pediatr Otorhinolaryngol 2013;77(9):1481-4. [CrossRef]

24. Duman D, Tekin M. Autosomal recessive nonsyndromic deafness genes: a review. Front Biosci (Landmark Ed) 2012;17:2213-36. [CrossRef]

25. Kelley PM, Harris DJ, Comer BC, Askew JW, Fowler T, Smith $\mathrm{SD}$, et al. Novel mutations in the connexin 26 gene (GJB2) that cause autosomal recessive (DFNB1) hearing loss. Am J Hum Genet 1998;62(4):792-9. [CrossRef]

26. Batissoco AC, Abreu-Silva RS, Braga MC, Lezirovitz K, DellaRosa V, Alfredo T Jr, et al. Prevalence of GJB2 (connexin-26) and GJB6 (connexin-30) mutations in a cohort of 300 Brazilian hearing-impaired individuals: implications for diagnosis and genetic counseling. Ear Hear 2009;30(1):1-7. [CrossRef]
27. Dalamon V, Fiori MC, Figueroa VA, Oliva CA, Del Rio R, Gonzalez W, et al. Gap-junctional channel and hemichannel activity of two recently identified connexin 26 mutants associated with deafness. Pflugers Arch 2016;468(5):909-18. [CrossRef]

28. Amorini M, Romeo P, Bruno R, Galletti F, Di Bella C, Longo $P$, et al. Prevalence of Deafness-Associated Connexin-26 (GJB2) and Connexin-30 (GJB6) Pathogenic Alleles in a Large Patient Cohort from Eastern Sicily. Ann Hum Genet 2015;79(5):341-9. [CrossRef]

29. Mahdieh N, Rabbani B. Statistical study of 35delG mutation of GJB2 gene: a meta-analysis of carrier frequency. Int J Audiol 2009;48(6):363-70. [CrossRef]

30. Azadegan-Dehkordi F, Ahmadi R, Koohiyan M, Hashemzadeh-Chaleshtori M. Update of spectrum c.35delG and c. $-23+1 G>A$ mutations on the GJB2 gene in individuals with autosomal recessive nonsyndromic hearing loss. Ann Hum Genet 2019;83(1):1-10. [CrossRef]

31. Tekin M, Duman T, Boğoçlu G, Incesulu A, Comak E, Ilhan I, et al. Spectrum of GJB2 mutations in Turkey comprises both Caucasian and Oriental variants: roles of parental consanguinity and assortative mating. Hum Mutat 2003;21(5):552-3. [CrossRef]

32. Subaşıŏlu A, Duman D, Sırmacı A, Bademci G, Carkıt $F$, Somdaş $M A$, et al. Research of genetic bases of hereditary non-syndromic hearing loss. Turk Pediatri Ars 2017;1;52(3):122-32. [CrossRef]

33. Uyguner $O$, Emiroglu M, Uzumcu A, Hafiz G, Ghanbari A, Baserer $N$, et al. Frequencies of gap- and tight-junction mutations in Turkish families with autosomal-recessive nonsyndromic hearing loss. Clin Genet 2003;64(1):65-9. [CrossRef]

34. Liu XZ, Yuan $Y$, Yan D, Ding EH, Ouyang XM, Fei $Y$, et al. Digenic inheritance of non-syndromic deafness caused by mutations at the gap junction proteins $\mathrm{C} \times 26$ and $\mathrm{C} \times 31$. Hum Genet 2009;125(1):53-62. [CrossRef]

35. Asma A, Ashwaq A, Norzana AG, Atmadini AM, Ruszymah $B H$, Saim L, et al. The association between GJB2 mutation and GJB6 gene in non syndromic hearing loss school children. Med J Malaysia 2011;66(2):124-8.

36. Rodriguez-Paris J, Schrijver I. The digenic hypothesis unraveled: the GJB6 del(GJB6-D13S1830) mutation causes allele-specific loss of GJB2 expression in cis. Biochem Biophys Res Commun 2009;13;389(2):354-9. [CrossRef]

37. Naseri M, Akbarzadehlaleh M, Masoudi M, Ahangari N, Poursadegh Zonouzi AA, Poursadegh Zonouzi A, et al. Genetic Linkage Analysis of DFNB4, DFNB28, DFNB93 Loci in Autosomal Recessive Non-syndromic Hearing Loss: Evidence for Digenic Inheritance in GJB2 and GJB3 Mutations. Iran J Public Health 2018;47(1):95-102.

38. Kim SY, Kim AR, Kim NKD, Lee C, Kim MY, Jeon EH, et al. Unraveling of Enigmatic Hearing-Impaired GJB2 Single Heterozygotes by Massive Parallel Sequencing: DFNB1 or Not? Medicine (Baltimore) 2016;95(14):e3029. [CrossRef]

39. Lechowicz U, Pollak A, Oziębło D, Ołdak M. Pathogenic p.Cys194Metfs*17 variant argues against TMPRSS3/ GJB2 digenic inheritance of hearing loss. Eur Arch Otorhinolaryngol 2016;273(5):1327-8. [CrossRef]

40. Kooshavar D, Tabatabaiefar MA, Farrokhi E, Abolhasani M, Noori-Daloii MR, Hashemzadeh-Chaleshtori M. Digenic inheritance in autosomal recessive non-syndromic hearing loss cases carrying GJB2 heterozygote mutations: assessment of GJB4, GJA1, and GJC3. Int J Pediatr Otorhinolaryngol 2013;77(2):189-93. [CrossRef] 
41. Ołdak M, Lechowicz U, Pollak A, Oziębło D, Skarżyński H. Overinterpretation of high throughput sequencing data in medical genetics: first evidence against TMPRSS3/ GJB2 digenic inheritance of hearing loss. J Transl Med 2019;14;17(1):269. [CrossRef]

42. Richard G, Brown N, Ishida-Yamamoto A, Krol A. Expanding the phenotypic spectrum of $\mathrm{C} \times 26$ disorders: Bart-Pumphrey syndrome is caused by a novel missense mutation in GJB2. J Invest Dermatol 2004;123(5):856-63. [CrossRef]

43. Essenfelder GM, Bruzzone R, Lamartine J, Charollais A, Blanchet-Bardon C, Barbe MT, et al. Connexin30 mutations responsible for hidrotic ectodermal dysplasia cause abnormal hemichannel activity. Hum Mol Genet 2004;15;13(16):1703-14. [CrossRef]
44. Shearer AE, Smith RJ. Massively Parallel Sequencing for Genetic Diagnosis of Hearing Loss: The New Standard of Care. Otolaryngol Head Neck Surg 2015;153(2):175-82. [CrossRef]

45. Sloan-Heggen $C M$, Bierer $A O$, Shearer AE, Kolbe DL, Nishimura CJ, Frees KL, et al. Comprehensive genetic testing in the clinical evaluation of 1119 patients with hearing loss. Hum Genet 2016;135(4):441-50. [CrossRef] 